\title{
直接慣性力制御を用いた制振・除振システムに関する研究*
}

\author{
田上将治*1, 田川泰敬*1, 安田正志*2 \\ 洞宏一*2, 野口保行*3, 加藤久雄 ${ }^{* 3}$
}

\section{Vibration Damping and Isolation Systems \\ Using Direct Inertia Force Control}

\author{
Masaharu TAGAMI, Yasutaka TAGAWA*4, Masashi YASUDA, \\ Hirokazu HORA, Yasuyuki NOGUCHI and Hisao KATO \\ ${ }^{* 4}$ Department of Mechanical Systems Engineering, Tokyo University of Agriculture and Technology, \\ 2-24-16 Nakacho, Koganei-shi, Tokyo, 184-8588 Japan
}

\begin{abstract}
Recently, active vibration control devices are widely used in many industrial fields. These are categorized into the following two types with their mechanisms. (A) Vibration is controlled by actuators whose one ends are connected to the controlled object and the other ends are connected to "the fixed floor or reaction walls". (B) Vibration is controlled by actuators whose one ends are connected to the controlled object and the other ends are connected to "the movable mass". Typical devices of (A) are active vibration isolation devices. The advantage of type (A) is excellent vibration control performance. However, it is difficult to downsize the devices, because the actuator has to support the controlled object. Meanwhile, typical devices of (B) are active mass dampers (AMD). In type (B), since the actuator doesn't need to support the controlled object, it is possible to realize compact systems. However, the control system design of type (B) tends to be complicated, especially for multi-axis plants. In this paper, we propose a new vibration control system design concept called "Direct Inertia Force Control (DIFC)". By using the DIFC, we can achieve the advantage of the type (A) and (B) simultaneously. Also the DIFC is able to cover the disadvantage of (A) and (B) cited above. Furthermore, the effectiveness of the DIFC is verified by using a newly designed one-degree of freedom active vibration control device, in experiment.
\end{abstract}

Key Words : Vibration Control, Active Mass Damper, Direct Inertia Force Control

\section{1. はじめに}

アクティブ振動制御装置は精密機器の除振，高層ビルの 制振や車両の乗り心地の改善など様々な分野で用いられて いる. このアクティブ振動制御装置を，その基本構造で分 類すると, (A)振動制御の対象となる機器をアクチュエー夕 と固定面を用いて支持し，振動制御を行うタイプ，(B)振動 制御の対象となる機器に付加質量を取り付け，その慣性力 を利用して振動制御を行うタイプ，に大別される(1). (A)夕 イプの代表にはアクティフ除振装置があり, 対象象器と設 置環境の振動を絶绿する目的で用いられる. 適用例として は半尊体露光装置などがある. このタイプはフィードフォ

\footnotetext{
* 原稿受付 2008 年 3 月 17 日.

*1 正員, 東京農工大学工学府 (画184-8588 小金井市中町 2-24 $16)$.

*2 正員, 特許機器(株) (雪 660-0833 尼崎市南初島町 10-133).

$* 3$ 特許機器 (株).

E-mail : tagawa@cc.tuat.ac.jp
}

ワード制御によって，振動絶縁性能を引き上げることが可 能であるが2)，対象を支持する構造であるため比較的大型の アクチュエータが必要になり小型のシステムを構成しにく い. (B)夕イプはActive mass damper (AMD) と呼ばれる装置 がその代表で，一般に対象の共振特性を抑㽵するために用

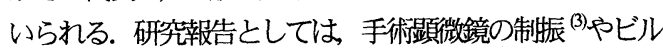
の制振などが挙げられる().このように(B)タイプは比較的 使い勝手よく装置を構成できるが, (A)夕イプのような振動 絶縁性能を得ることは一般に困難である.また，多軸 (対 象の運動の方向が単一方向でないこと) への対応も(A)夕イ プの場合と比べて複雑になる，そこで本論文では，両者の 長所を取り込んだ振動制御装置を構成する手法を提案する. 本手法は，制卸入力として慣性力を用いる方法で(B)夕イプ に属するが，対象に作用させるべき振動制御力を慣性力制 御によって生成して対象に作用させる点が異なる. この慣 性力を直接的に制御して振動制御を行う手法を我々は “直 接慣性力制御 (Direct Inertia Force Control, 以降'DIFC”) ” と 


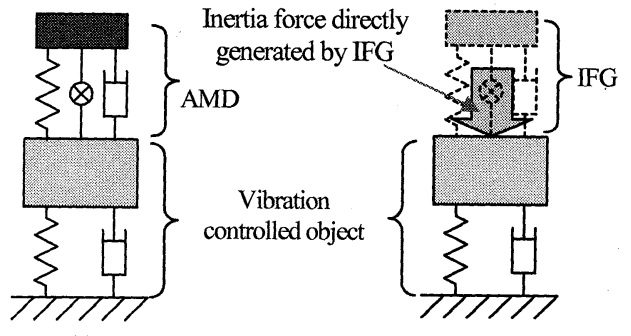

(a) AMD

(b) DIFC

Fig. 1 Conceptual view of the DIFC

呼ぶ 詳細は後述するが, DIFCにより多軸振動制御系の設 計負荷を低减C゙き，また，(A)タイプの長所である振動絶縁 性能の向上，さらに著者らが提案する “消振”(といった各 種の振動制御の実現が容易になる. 本論文ではこの DIFC のコンセプトについて紹介するとともに，DIFC に基づく 1 軸制振・除振システムを試作し, 制御性能評価を行つた結 果について述べる.なお，本論文中では制振とは振動制御 したい対象（例えばパッシブ除振系）の共振特性を抑圧さ せることを意味する. また除振とは対象に伝達する設置環 境振動を絶縁することを意味する。

\section{2. 直接慣性力制御（DIFC）}

$2 \cdot 1$ DIFC のコンセプトＤIFC のコンセプトを 1 軸 $\mathrm{AMD}$ と対比しながら説明する. AMD によって制振 制御を行う場合，図 1(a)に示すように対象とする振動 系に AMD を設置する. この場合, 制振対象が 1 自由 度振動系であったとしても制御器設計は 2 自由度振動 系のモデルで進めなければならない. 一方で, DIFCで は振動制御に必要な力を慣性力制御によって生成し, これを対象に直接作用させて振動を制御する.このた め DIFC では, 図 1(b)に示すように AMD の代わりに指 令した慣性力を迅速かつ正確に発生するデバイスであ る慣性力発生装置(Inertia Force Generator, 以降'IFG') を用いる. IFG のハードウェアは基本的には AMD と 同じであるが，IFG は可動質量に加速度センサを搭載 しており, 加速度制御器により可動質量の加速度を制 御することで任意の慣性力を発生する装置である。こ れにより振動制御系全体の設計では IFG の動特性を無 視でき，直接力が振動制御対象に作用するシステムと して扱うことができる. DIFC の利点をまとめると以下 のとおりである. (1) 1 軸 $\mathrm{AMD}$ では 2 自由度振動系を 基に制御器設計を進めたが, DIFC では図 1(b)のように 1 自由度振動系を基に制御器設計を進めることができ る.これは設計の見通しを改善でき，特に次節で示す 多軸制御の場合では顕著である. (2) DIFC を用いた場 合，振動制御対象の力学モデルは前章で紹介した(A) タイプと等価となる. よって DIFC を用いれば，アク
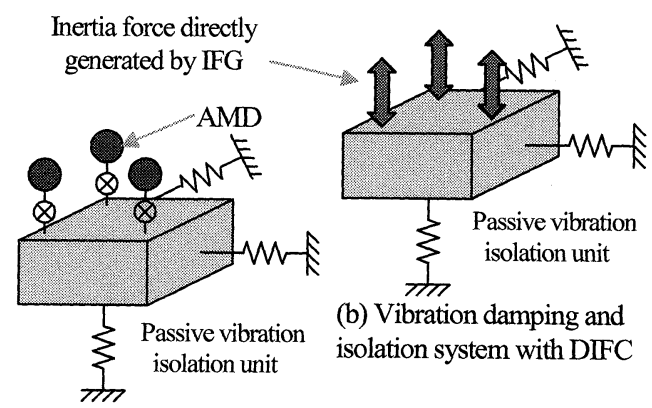

(b) Vibration damping and isolation system with DIFC

(a) Vibration damping system with AMD

Fig. 2 Multi-axis vibration control system

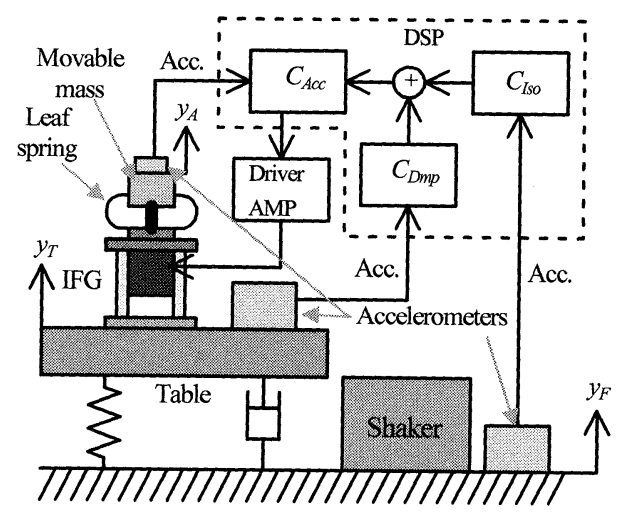

Fig. 3 Schematic view of the 1-DOF active

vibration damping and isolation system

ティブ除振装置の特徽的な機能（フィードフォワード 制御による除振機能強化など）を比較的簡単に取込め る.

2・2 DIFC による多軸振動制御 図 2(a)に示すよう に複数の $\mathrm{AMD}$ を用いて, 複数の運動モードの制振制 御を行う多軸 $\mathrm{AMD}$ を設計する場合, $\mathrm{AMD}$ 自身の動特 性によってモデルの次数が増加し, 制御器設計が大変 複雑になる(の). 一方で, DIFC を用いれば, 図 2(b)の様 に直接対象に力が作用するシステムとして扱える.こ の上で, さらにモ一ド解析を用いれば，多軸振動制御 器の設計を複数の 1 自由度振動系に対する制御器設計 に置き換えることができる，この様に DIFC はモード 解析と組夕合わせることで, 多軸振動制御系に対して も強力な効果を発揮する.

\section{DIFC による 1 軸制振・除振システム}

$3 \cdot 1$ ハードウェアの構成 本研究では, DIFC の有 効性確認のため, DIFC に基づく 1 軸アクティブ制振 . 除振システムを試作した. 図 3, 図 4 に本システムの 概略図と概観写真を示す．本システムはパッシブ除振 系で支持された簡易定盤 $(400 \mathrm{~mm} \times 500 \mathrm{~mm}, 19 \mathrm{~kg})$ を対 


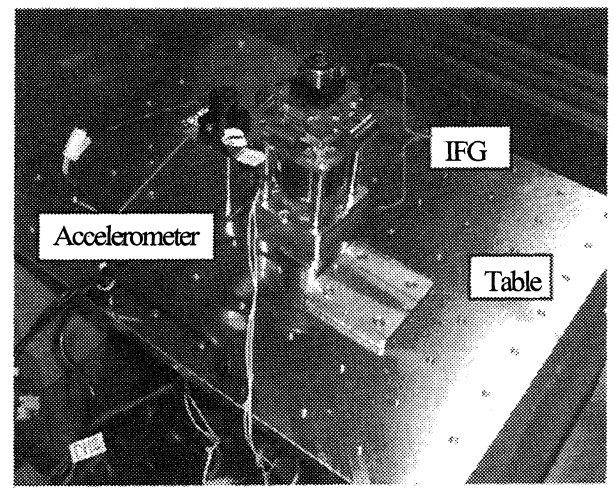

Fig. 4 Picture of the 1-DOF active vibration damping and isolation system

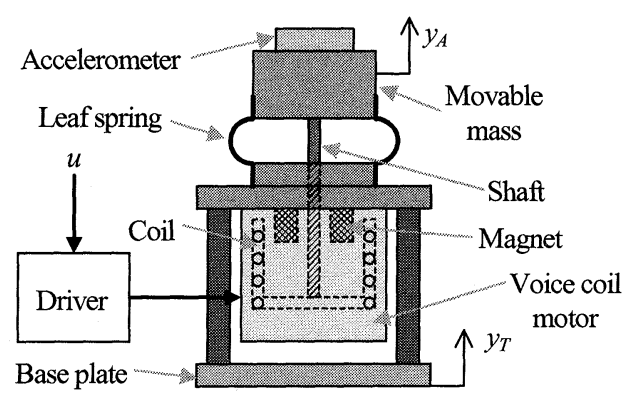

Fig. 5 Schematic view of the IFG

象として，制振機能と除振機能を実現する. 図 3 中の $y_{A}$ は IFG の可動質量に発生する加速度, $y_{T}$ は定盤上の 加速度で, IFG にとっては設置面加速度であり, 外乱 となる. また $y_{F}$ は設置環境の振動加速度で, 今後, 環 境外乱之呼ぶ，図 5 に DIFC を用いる上で重要な役割 を果たす IFG（慣性力発生装置）の模式図を示す. IFG は板ばねで支持された可動質量, 可動質量に取り付け られた加速度センサ, ボイスコイルモータとその駆動 用ドライバで構成される. 図 5 中の $u$ はドライバへの 指令電圧である.

$3 \cdot 2$ 制御系全体の構成 図 3 を用いて制御系全体 の構成を説明する. $y_{A}$ は加速度制御器 $C_{A C C}$ で制御され る. DIFC を用いる場合，振動制御対象への制御入力は 慣性力であり,この制御された加速度に可動質量の大 きさを乗じれば, 慣性力となる. しかし, 実際には可 動質量には案内機構, ばね要素やセンサ周辺の配線な ど複雑な要素が含まれ，正確な大きさを見積もること は困難である.そこで振動制御系の設計ではプラントへ の制御入力は慣性力ではなく IFGが発生する加速度 $y_{A}$ とし た.これにより，可動質量は振動制御奶象に含まれそその 值を求める必要はなくなる. 制振機能は $y_{T}$ を入力とする フィードバック制御器 $C_{D m p}$ により実現される. さらに
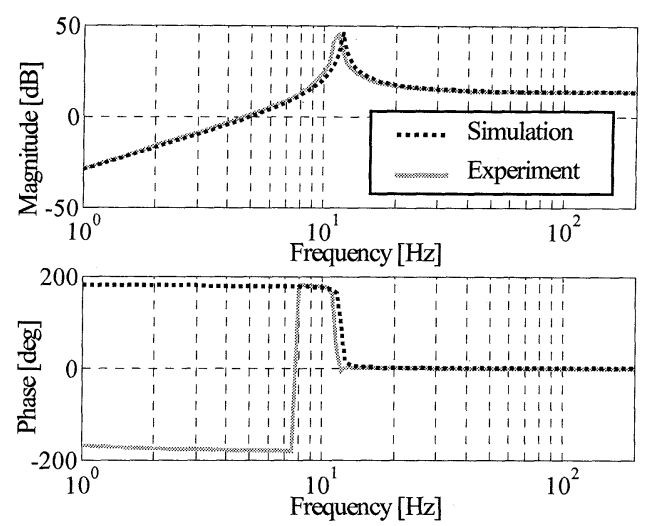

Fig. 6 Frequency response of $P_{A u}$

除振機能は, 加速度センサにて測定した $y_{F}$ を入方す るフィードフォワード制御器 $C_{I s o}$ で実現される. 以上 より，試作したシステムの制御系は $C_{D m p}, C_{I s o}$ が IFG に発生させるべき加速度を決定し， $C_{A c c}$ がその加速度 を実現するように IFG を制御する構成であることが分 かる.

\section{4. 制御系設計}

前章で述べた 1 軸アクティブ制振・除振システムを構成 する3つの制御器の設計について述べる.

$4 \cdot 1$ 加速度制御器 $C_{A c C}$ の設計 まずIFG のプラント モデルを導出する. IFG のプラントモデルは $P_{A u}$ と $P_{A d}$ という 2 つ伝垟関数で表現される. 図 5 において, $P_{A u}$ は $u$ から $y_{A}$ までの伝達特性を支配し, $P_{A d}$ は $y_{T}$ から $y_{A}$ までの伝達特性を支配する. 両者はそれぞれ下式の ように与えられる. ただし $K_{A}$ はアンプゲイン, $\xi_{A}, \omega_{n A}$ はそれぞれIFG の洬衰比と固有角振動数である.

$$
\begin{gathered}
P_{A u}=\frac{K_{A} s^{2}}{s^{2}+2 \xi_{A} \omega_{n A} s+\omega_{n A}{ }^{2}} \\
P_{A d}=\frac{2 \xi_{A} \omega_{n A} s+\omega_{n A}{ }^{2}}{s^{2}+2 \xi_{A} \omega_{n A} s+\omega_{n A}{ }^{2}}
\end{gathered}
$$

図6に実則した $P_{A u}$ の周波数応答を示す.この結果より高 周波の平坦部のゲインから $K_{A}$ を, ゲインのピーク值とその ときの周波数から $\omega_{n A}$ と宏を同定し, $K_{A}=4.97, \omega_{n A}=75.37 \mathrm{rad} / \mathrm{s}$, $\xi_{A}-0.0125$ を得た。これらの数值を用いた周波数応答のシミ ユレーション結果も図 6 に示す. 図より同定したプラント モデルと実際の特性はよく一致することが分かる.

次に DIFC を用いる上で, 非常に重要な要素である IFG の加速度制御器 $C_{A c c}$ の設計ついて説明する. IFG はパッ シブ除辰系上で使用されるため, 外乱となる $y_{T}$ の影響が大 きいと考えられる. その上で，上位の制御器である $C_{D m p}$ や 


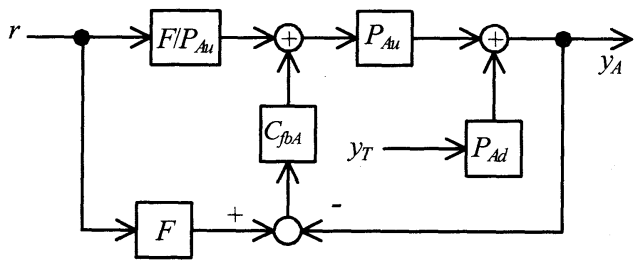

Fig. 7 Block diagram of the acceleration control system for the IFG

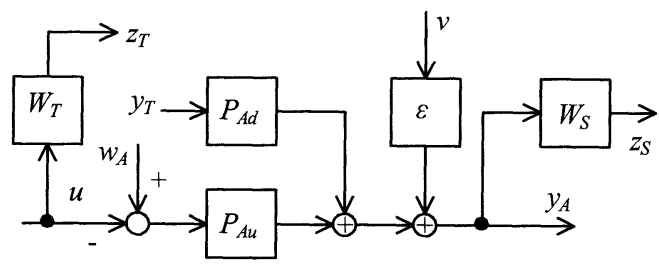

Fig. 8 Generalized plant for the IFG acceleration control system

$C_{\text {bo }}$ から使いやすいように優れた追従特性が求められる. そ こで, $C_{\text {Acc }}$ は図7に示す様な 2 自由度制御系て構成した。 図7 中の $C_{b A}$ はフィードバック制御器, $F$ は指令入力 $r$ から $y_{A}$ までの害現したい伝達特性である. $C_{\text {品 }}$ が外乱やモデル化 誤差を十分抑圧すれば, $r$ から $y_{A}$ までの伝達特性はこの $F$ に一致する. また $C_{\text {faA }}$ は外乱抑班性能に着目して, $H_{\infty}$ 制御 理論によって設計した。設計に用いた一般化プラントを図 8 に示す. 図中の $W_{S}, W_{T}$ は重み関数 $z_{S}, z_{T}$ は产価量 $v$ は 観則ノイズ, $\varepsilon$ は定数， $u$ は制御入力, $w_{A}$ は外乱である. 重 夕関数の設計は以下の指針基づいて行った. $W_{T}$ はロバス 卜安定性を確保するため, $P_{A t}$ の乗法的誤差を覆うように定 めた．また同時に，IFG のストロークを考慮して低周波で の制御ゲインを小さくすることと, 高周波での観測ノイズ の抑在も目標とした。このため $W_{T}$ は，DCに近い低周波と 観測ノイズの多い高周波で高いゲインを持つように定めた。 $W_{S}$ は制御带域人で $y_{T} か ゙ y_{A}$ に及ぼす影響をなるべく抑圧でき

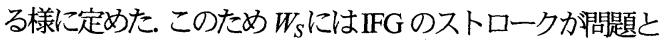
なる低周波と観則ノイズが多い高周波では低いゲインを, 外乱抑圧が必要な帯域では高いゲインを持たせた．以上の 指針に基づき, 重夕関数を式(3)〜式(5)のように定めた。 た だし, $T_{T 1}=1 /(2 \pi \times 0.01) \mathrm{s}, \quad T_{T 2}=T_{T 3}=1 /(2 \pi \times 2.7) \mathrm{s}$, $T_{T 4}=1 /(2 \pi \times 4000) \mathrm{s}, \quad K_{W T}=24, \quad K_{W S}=400$, $\omega_{n s 1}=2 \pi \times 0.5 \mathrm{rad} / \mathrm{s}, \quad \zeta_{s 1}=0.8, \omega_{n s 2}=2 \pi \times 40 \mathrm{rad} / \mathrm{s}$, $\zeta_{s 2}=0.8$ とした.

$$
\begin{aligned}
& \varepsilon=0.002 \\
& W_{T}=K_{W T} \frac{T_{T 1}}{T_{T 2}} \cdot \frac{1+T_{T 2} s}{1+T_{T 1} s} \cdot \frac{1+T_{T 3} s}{1+T_{T 4} s}
\end{aligned}
$$

$$
W_{S}=K_{W S} \frac{s^{2}}{s^{2}+2 \zeta_{s 1} \omega_{n s 1} s+\omega_{n s 1}{ }^{2}} \cdot \frac{\omega_{n s 2}{ }^{2}}{s^{2}+2 \zeta_{s 2} \omega_{n s 2} s+\omega_{n s 2}{ }^{2}}
$$

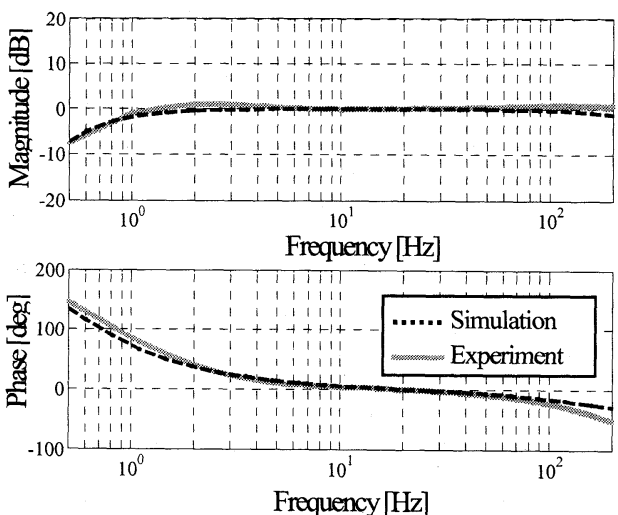

Fig. 9 Reference tracking performance of IFG

以上の一般化プラントに対して MATLAB を用いて制御器 を求めた. 求めた制御器を用いた閉ループ外乱抑圧性能と $P_{A d}$ を周波数応答にて比較した. 結果は紙面の都合上省略す るが，良好な外乱抑圧特性が確認された。. 次にフィードフ オワード制御器である $F$ と $F / P_{A u}$ の設訊について述べる. 制 御器に課せられる条件は, (1)制御器力安定であること, (2)F 及び $F / P_{A u}$ がDCゲインを持たないこと, (3)rから $y_{A}$ までの 伝達特性が带域通過特性であること，である． $P_{A u}$ は与えら れるため $F / P_{A u}$ は

$$
\frac{F}{P_{A u}}=F \frac{s^{2}+2 \xi_{A} \omega_{n A} s+\omega_{n A}{ }^{2}}{K_{A} s^{2}}
$$

となるが, $P_{A u}$ の不安定零点は(1)の観点から好ましくない. また, (2)の観点から DCカットのため Fには微分特性が必 要である. したがって, $F$ の分子多項式には $s^{3}$ を因数に持 たせる必要がある. さらに, $F$ がプロパーであるためには $F$ の分母多項式の次数は 3 次以上必要となる. この上で(3)を 满たすためには， $F$ は 3 次の高域通過特性と最低でも 1 次 の低域通過特性を持たなければならない.したがって, $F$ は式(7のように与えられる.

$$
F=\frac{T_{F H} s^{3}}{\left(s^{2}+2 \xi_{F} \omega_{n F} s+\omega_{n F}{ }^{2}\right)\left(1+T_{F H} s\right)} \cdot \frac{1}{T_{F L} s+1}
$$

ただし, $T_{F H}=1 /(2 \pi \times 0.5) \mathrm{s}, \quad T_{F L}=1 /(2 \pi \times 350) \mathrm{s}$, $\omega_{n F}=2 \pi \times 0.5 \mathrm{rad} / \mathrm{s}, \quad \xi_{F}=0.8$ とした.これは必要とする 加速度制御の帯域力数へルツから数十へルツ程度であるた め,この帯域大でゲイン特性，位相特性が共に平坦であれ ばよいと考えたためである.

設計した加速度制御器 $C_{A c}$ をDSP に実装して性能を評価 した. 性能師価ではFFT アナライザを用いて目標值追従特 性を実則しシシュレーションと比較した，結果を図 9 に 示す. 図よりシミュレーションとよく一致した意四通りの 性能力得られていることが分かる。 

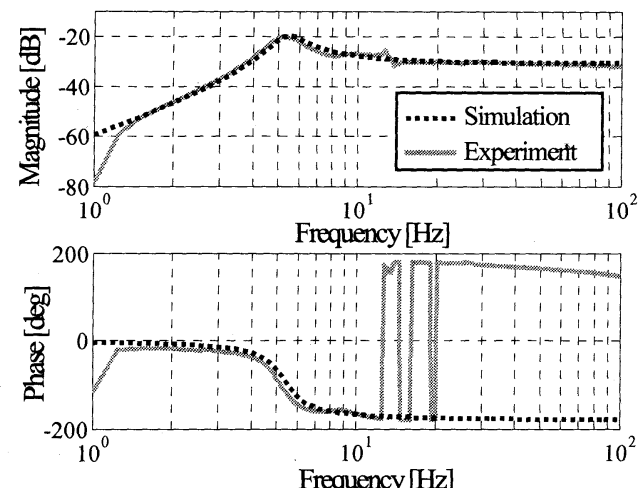

Fig. 10 Frequency response of $P_{T u}$

4 -2 制脤制御器 $C_{D m p}$ の設計 プラントの共振特性 を抑圧する, 制振制御器 $C_{D m p}$ について述べる. まず $C_{D m p}$ の設診のためにプラントのモデルを導出する. 制振制御器 に対するプラントは図 3 に示すように，簡易定盤とパッシ ブ除振系およびIFG で構成される. これより，プラントモ デルは $y_{A}$ から $y_{T}$ までを支配する伀達関数 $P_{T u}$ 亡環境外乱で ある $y_{F}$ から $y_{T}$ までを支配する伝達関数 $P_{T d}$ で与えられる. 式(8), 式(9)にこれらの伝達関数を示す.

$$
\begin{aligned}
& P_{T u}=-\frac{K_{T} s^{2}}{s^{2}+2 \xi_{T} \omega_{n T} s+\omega_{n T}{ }^{2}} \\
& P_{T d}=\frac{2 \xi_{T} \omega_{n T} s+\omega_{n T}{ }^{2}}{s^{2}+2 \xi_{T} \omega_{n T} s+{\omega_{n T}}^{2}}
\end{aligned}
$$

ただし， $K_{T}$ はゲイン， $\omega_{n T}, \xi_{T}$ はそれぞれパッシブ除振系の 減衰比之固有角振動数である. モデルの各パラメ夕は同定 実験により決定した，同定実験は図 3 の装置構成で, $C_{D m p}$ と $C_{\mathrm{Bo}}$ を用いない, IFGと $C_{A c c}$ のみが存在する状態で行った. FFT アナライザで生成したスイープサイン波を IFG の目標 加速度として $C_{A c c}$ に入力し，定盤を加振した．このときの $y_{A}$ と $y_{T}$ を測定し, FFT アナライザにより $y_{A}$ から $y_{T}$ までの周 波数応答を取得した，測定結果を図 10 に示す.この結果と 4・1 節の IFG のパラメ夕同定に用いた手法を利用して $K_{T}=0.03, \xi_{T}=0.149, \omega_{n T}=33.75 \mathrm{rad} / \mathrm{s}$ を得た. さらに, 式(8) と同定した上記パラメタを用いて周波数応答のシミュレー ションを行つたこの結果も図 10 に示す.シミュレーショ ン結果と実則結果はよく一致しており良好なプラントモデ ルが得られたといえる.

制振制御器 $C_{D m p}$ は $H_{\infty}$ 制御理論を用いて設計した. 制御 器設計ではIFG の特性は理想的であるとして，その特性は 無視して設計を進めた．つまり， $C_{D m p}$ が IFG に要求した加 速度は值ちに発生できるものとして扱っている. このよう に扱えることに DIFC の利点がある. $C_{D m p}$ の設計は $C_{f a A}$ と 同様に進めたため, 用いた一般化プラントは眓 8 と同様で

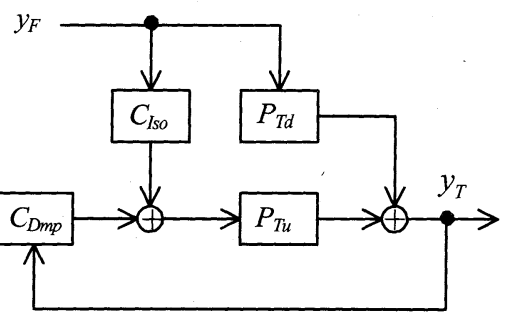

Fig. 11 Block diagram of the control system for the active vibration damping and isolation system

ある. 図中の記号も同様であるが， $P_{A u}$ と $P_{A d}$ がそれぞれ $P_{T u}$ と $P_{T d}$ に置き換わる点が異なる. また，重み関数の関数 形も式(3)〜式(5) と同様であるが, パラメ夕は $K_{W T}=3$, $T_{T 1}=1 /(2 \pi \times 2) \mathrm{s}, \quad T_{T 2}=1 /(2 \pi \times 1000) \mathrm{s}, \quad T_{T 3}=1 /(2 \pi) \mathrm{s}$, $T_{T 4}=1 /(2 \pi \times 0.005) \mathrm{s}, K_{W S}=53, \omega_{n s 1}=2 \pi \times 4.5 \mathrm{rad} / \mathrm{s}$, $\zeta_{s 1}=0.25, \omega_{n s 2}=2 \pi \times 30 \mathrm{rad} / \mathrm{s}, \zeta_{s 2}=0.25, \varepsilon=0.001$ とした. 以上の一般化プラントと重み関数を基に制御器を 求めた，求めた制御器による制誫性能は 5 章にて示す.

$4 \cdot 3$ 除振制御器 $C_{\mathrm{LD}}$ の設計 除振機能を実現するフィ ードフォワード制御器 $C_{\mathrm{Io}}$ の設詰けについて述べる. $C_{\mathrm{Bo}}$ の目 的は，定般に伝播した環境外乱 $y_{F}$ の影響をIFGによって打 ち消すことである. 除振のための制御入力は $y_{F}$ 基に計算 される. 図 3 及び式(8); 式(9)より制振・除振制御系のブロ ック線図は図 11 のようになる. このブロック線図より式 (10)が成立する.

$$
y_{T}=\left(\frac{P_{T d}+P_{T u} C_{I s o}}{1-P_{T u} C_{D m p}}\right) y_{F}
$$

式(10)より, $y_{T}=0$ とするためには $C_{I S o}=-P_{T d} / P_{T u}$ が成 立すればよい. しかし， $P_{T u}$ は不安定零点を持つため, この ままでは $C_{b o}$ は不安定な制御器となり望ましくない. そこで, $C_{I s o}=-P_{T d} / P_{T u}$ の分母多項式を擬似積分器で置き換えた 次式を実際に使用する除振制御器 $C_{\mathrm{Iso}}$ とした。

$$
C_{I s o}=\frac{2 \xi_{T} \omega_{n T} s+\omega_{n T}^{2}}{K_{T}\left(s^{2}+2 \xi_{s} \omega_{n s} s+\omega_{n s}^{2}\right)}
$$

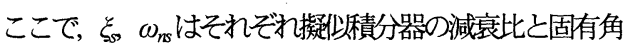
振動数である. 以上より最終的な除振性能は式(11)を 式(10)に代入して得られる下式によって与えられる.

$$
y_{T}=\frac{2 \xi_{s} \omega_{n s} s+\omega_{n s}{ }^{2}}{s^{2}+2 \xi_{s} \omega_{n s} s+\omega_{n s}{ }^{2}} \cdot \frac{P_{T d}}{1-P_{T u} C_{D m p}} y_{F}
$$

上式の $P_{T d} /\left(1-P_{T u} C_{D m p}\right)$ は, 制振制御性能を意味する. この ため, 最終的な除振性能は制脤性能に低域通過特性を作用 させた関数形となり, 除振性能は擬似積分器の極が大きな 影響を与えることになる. このためなるべく虚軸近傍に擬 
似積分器の極を配置したいが，あまり虚䡛に近いと制御ゲ インが大きくなり，IFG のストロークの制約を受ける.こ のため今回は $\omega_{n s}=2 \pi \mathrm{rad} / \mathrm{s}, \xi_{\mathrm{s}}=0.8$ とした.

\section{5. 性能評価}

4 章で述べた各制御器を実装して, 制誫・除振性能を実験 にて評価した。性能評価は図 3 の装置を用いて，環摬外乱 がぞの程度定般に伝達するかを周波数応答にて評価した。 実験は以下の手順て行った。

・FFT アナライザで生成するスイープサイン波を指令信号 として動作する加振器にて作業台を加振し, 仮想的な環 境外乱を生成した

・このときの環競外乱 $y_{F}$ と定盤上加速度 $y_{T}$ をそれぞれ加速 度センサで則定した。

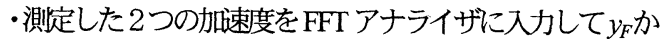
ら $y_{T}$ までの周波数応答を得た。

実験の比較条件は，制御を行わない場合 (プラント特性)， 制振制御のみを行う場合，制振制御之除振制御両方を行う

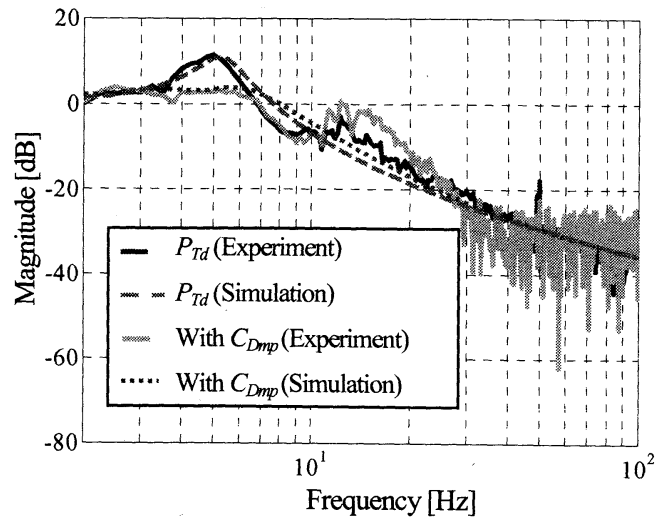

Fig. 12 Experimental and simulation results ( $P_{T d}$ vs with $C_{D m D}$ )

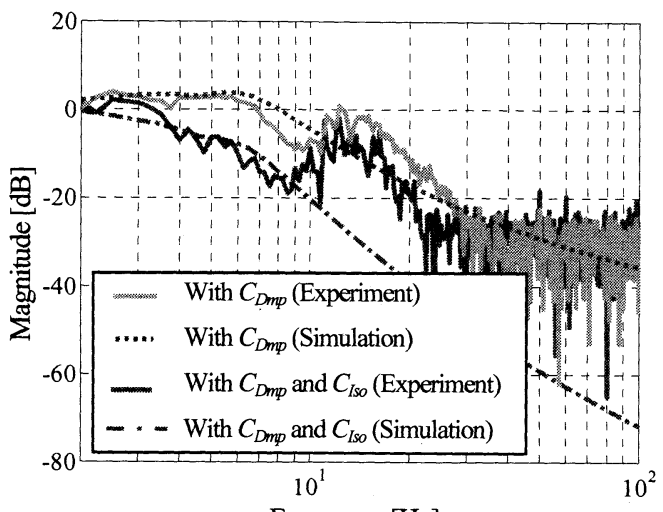

Frequency $[\mathrm{Hz}]$

Fig. 13 Experimental and simulation results (with $C_{D m p}$ vs with $C_{D m p}$ and $C_{I s o}$ )
場合の3つである. 図12にプラント特性と制振制御器 $\left(C_{D m m}\right)$ による制御性能の比較を, 図 13 に制振制御器 $\left(C_{D n q}\right)$ と制 振・除振制御器 $\left(C_{D n p}, C_{\mathrm{ID}}\right)$ による制御性能の比較を示す. 制振制御器は $5 \mathrm{~Hz}$ 付近に $10 \mathrm{~dB}$ 程度あった対象の共振特性 を十分抑圧し(図 12)，除振制御器はこの上でさらに環境外 乱の伝達を $10 \mathrm{~dB}$ 程度抑圧しており(図 13), 最大で $20 \mathrm{~dB}$ 近 (除振性能の向上が実現できた。 また，シミュレーション 結果もほぼ実験結果と一致している. $15 \mathrm{~Hz}$ 近傍の共振特性 は今回設計に考慮しなかった運動モードの影響し思われる。 これは今後, 多䡛制御可能なシステムに拡張することで解 決できると考えられる.

\section{6. おわりに}

本論文では，新たな振動制御手法として直接慣性力制御 (DIFC) を提案し，従来不難であった振動制御器の設計を 見通しよく進められることを示した，さらに，DIFC を用 いた 1 軸アクティブ制振・除辱装置を試作し，実験により その有効性を確認した。

\section{謝 辞}

本研究は，独立行政法人科学技術振興機構に扩りる産学 共同シーズイノベーション化事業顕在化ステーシ課題の一 環として実施された.ここに謝意を表する。

\section{文献}

(1) Seto, K., Vibration Control of Structure, (2006), pp.26-27, CORONA PUBLISHING

(2) Tagawa, Y., Seino, Y., Yasuda, M., Study of 6-DOF Microvibration Control Using Feedforward Control, Transactions of the Japan Society of Mechanical Engineers, Series C, Vol. 63, No.608 (1997), pp. 1081-1087.

(3) Fujita, T., Ikeda, K., Yasuda, M., Matsuura, A., Tsuchiya, M., Microvibration Control of Surgical Microscopes with Active Dynamic Vibration Absorbers, Transactions of the Japan Society of Mechanical Engineers, Series C, Vol. 66, No.651 (2000), pp. 3607-3612.

(4) Fujita, T., Bessho, T., Hora, H., Tanaka, K., Nakamura, Y., Control Methods for Active Mass Damper Using Linear Motor for Vibration Control of Tall Buildings, Transactions of the Japan Society of Mechanical Engineers, Series C, Vol. 64, No.620 (1998), pp. 1154-1161.

(5) Tagami, M., Yamashita, T., Tagawa, Y., Yasuda, M., Hora, H., Endo, K., Noguchi, Y., Development of an Active Vibration Cancelling System Using Inertial Force Generator, Transactions of the Japan Society of Mechanical Engineers, Series C, Vol. 73, No.735 (2007), pp. 2948-2954

(6) Nogawa, N., Tagami, M., Tagawa, Y., Yasuda, M., Hora, H., Noguchi, Y., Kato, H., Study of an Active Vibration Cancelling and Damping System Using Inertial Force Generator, $50^{\text {th }}$ Automation Control Joint Conference, Abstract book, (2007), pp. 973-978. 